\title{
Institutional Related Factors Affecting the Implementation of Strategic Plans in Local Authorities in Kenya: A Case of Municipal Council of Eldoret
}

\author{
Peter I. Buluma ${ }^{1}$, Isaac K. Keror ${ }^{2} \&$ John M. Bonuke ${ }^{3}$ \\ ${ }^{1}$ School of Law, Mount Kenya University, Eldoret, Kenya \\ ${ }^{2}$ School of social Sciences, Mount Kenya University, Eldoret, Kenya \\ ${ }^{3}$ School of Business, Moi University, Yala, Kenya \\ Correspondence: Peter I. Buluma, School of Law, Mount Kenya University, P.O. Box 2591-30100, Eldoret, \\ Kenya. Tel: 254-725-961-758. E-mail: bulumapeteri@gmail.com
}

Received: February 18, 2013 Accepted: March 22, 2013 Online Published: April 18, 2013

doi:10.5539/ijbm.v8n10p81 URL: http://dx.doi.org/10.5539/ijbm.v8n10p81

\begin{abstract}
The study sought to determine effects of institutional related factors, affecting the implementation of strategic plans in local authorities in Kenya with a view on the Municipal council of Eldoret strategic plan. The study adopted a descriptive research design on a sample of 254 respondents who were selected through purposive, stratified and snowball sampling from a target population of 836 employees. Data collection was done by the use of questionnaires and interview schedules and the data analyzed by the aid of Statistical Package of Social Scientists Program (SPSS). The findings were summarized using statistical measures of central tendency, measures of dispersion and asymmetry. Data was presented using tables. Based on the study findings it was concluded that Municipal council of Eldoret faced challenges in the implementation of her strategic plan. This included institutional related factors, such as inadequate technological resources, insufficient management systems, and limited control over the implementation of the strategic plan, insufficient management approaches and inadequate support from the central government. The study recommended that the Municipal council of Eldoret should recruit enough expertise, review its management strategies, and provide adequate technical resources and a friendly working environment.
\end{abstract}

Keywords: institutional related factors, implementation of strategic plans, local authorities

\section{Introduction}

The transforming and transformed countries have since the 1980s embraced reforms that focused on the management of the public sectors which resulted to the public sector being put under pressure to adopt private sector orientations (Economic for Africa Report, 2003). As a result of the pressure, Hope (2001) observed that many governments adapted the use of New Public Management as a framework through which governments were modernizing the sectors owned by the public and re-engineering, indeed, NPM offered important lessons and analysis for public management throughout the world and African countries had no exception to the process of implementation of efforts aimed at achieving the outcomes embodied in the said framework.

According to the Economic for Africa Report (2003), the availability of Local Authorities as tools used by the African governments to implement developmental objectives, had to be put under pressure to adopt incentives which were inspired by NPM policies such as strategic management which advocated for the development and implementation of strategic plans. Wright (2003) indicated that the planning of strategies dictates the direction of an organization for a year or more. Therefore, for an organization to be able to achieve its targeted strategic objectives the entire organization should be involved. Strategic plans may fail to produce the desired results as noted by (Noble, 1999) who said that "organizations may have formulated the best strategies but the strategies may fail to produce the desired results if they are not implemented in the right way".

Various studies have focused on institutional related factors affecting implementation of strategies in organizations. For instance, Yang (2008) referred the highest management team in an organization as senior leaders who included the organizations Presidents, stakeholders, executive and senior level mangers. The board 
is one of the key subjects in the implementation of strategies as per Schmidt and Braurer (2006) findings.

Herbiniak and Snow (1982) findings indicated that, the participation and the interventions among the highest level of management in an organization promotes greater commitment levels in the implementation of a firms vision and strategies which intern promotes success in the implementation of a firms selected strategy while Smith and Kofron (1996) believed that the senior management played a major role not only in the formulation, but in the implementation of the strategy.

Nutt (1986) suggested that the tactics used in leadership styles may play important roles in overcoming obstructions from the lower levels that sometimes my appear in the implementation strategies. Nutt (1987) noted that strategic decisions formulated by the top-managers of a firm may be administratively imposed on lower-level managers and non-managers while inadequately considering the resulting functional level perceptions.

The implementation of strategies therefore, may not be successful if the lower level managers and the non-management employees are not adequately informed on issues concerning the implementation of strategies, moreover, where the information passes through several management levels in an organization may lead to lack of consensus concerning the information hence creation of a barrier that hinders the success of implementing a strategy (Noble, 1999).

According to Alexander (1985) findings, communication was among the most frequently mentioned item which was behind the promotion of successful implementation of a strategy. Therefore effective communication should explain clearly the new responsibilities, duties and tasks which are to be done by the targeted employees. Chimanzi and Morgan's (2005) study indicated that firms which focus their attention to marketing and involvement of all employees significantly realize higher percentages of strategy implementation. Therefore, Chimanzi and Morgan's (2005) proposed that managers in charge of marketing should focus on improving relationships with the their counterparts (human resource) by advocating for communication which is written and reward systems which are joint hence putting more emphasize on a two way process based dimension.

Heide, Gronhaug and Johannessen (2002) observed that there existed various communication related challenges. The communication related issues could have been brought about by the structure of the organization which intern leads to the creation of a barrier to the implementation of the strategic activities which had been planned. Rapert, Velliquette and Garretson (2002) observed that shared communication and understanding among human resources is an important aspect in strategy implementation process. For instance, through communicating vertically, the shared understanding about the prioritized strategies are likely to be enhanced hence leading to improvements.

Forman and Argenti (2005) observed that, the arrangements between the implementation of strategies and the communication functions of corporations where observable in that the firms were undergoing visible and very important strategic changes. For instance, they observed that the firms that they had studied had been involved in ensuring communication within the organization was felt and that information technology was the centre of ensuring the implementation of a strategy and the building of reputation.

\section{Material Studied}

The researcher used both primary and secondary data. Secondary data was obtained from journals, Municipal councils of Eldoret records, Government records, books, news papers, statistical abstracts and economic surveys.

\section{Area Description}

The study was carried out in Municipal council of Eldoret which is the administrative centre for Eldoret Municipality. The Municipality is located approximately $300 \mathrm{~km}$ North West of Nairobi and $65 \mathrm{~km}$ north of the Equator. Eldoret town is amongst the five largest towns in Kenya which hosted in this Municipality (Municipal Council of Eldoret, 2008-2013). Eldoret is a business hub in the Western part of Kenya as it is an administration centre for Eldoret East, Wareng and Eldoret districts. Eldoret Municipality measures approximately 147 square $\mathrm{km}$, with a population estimate of over 500,000 residing in areas such as Kamukunji, Langas, Munyaka and Kapsoya estates. The researcher selected the study area because it consists of the Municipal council of Eldoret which is the local administrative unit for this municipality, therefore this area was essential for the study as the researcher intended to study the implementation of strategic plans in local authorities.

\section{Methods}

\subsection{Research Design}

The study employed a descriptive research design. Orodho (2002) stated that descriptive research design is 
important in carrying out both exploratory and preliminary studies as it permits researchers in collecting information, summarizing and interpreting with the view of clarifying the information. While Mugenda and Mugenda (1999) on the other hand gave the purpose of descriptive research as determining and reporting the way things are.

\subsection{Target Population}

According to Borg \& Gall (1989), target population is defined as all the members of a real or hypothetical set of people, events or objects to which a researcher wishes to generalize the results of the research study. Therefore, the study targeted a total population of 836 employees, who comprised of 176 employees from the Towns Clerk Department, 159 from the Treasury, 109 from the Public Health Department, 184 from the Environment Department, 33 from Social Services and Housing, 58 from Education Department and 117 from the Engineering Department.

\subsection{Data Collection}

The researcher employed the use of secondary and primary data where by the secondary was obtained from journals, Municipal councils of Eldoret records, Government records, books, news papers, statistical abstracts and economic surveys while primary data was obtained using questionnaires and interviews. Questionnaires were used for data collection because they offered considerable advantages in administration. They present an even stimulus potentially to large numbers of people simultaneously and provide the investigation with easy accumulation of data. Gay (1992) pointed out that questionnaires give respondents an opportunity of expressing views and making suggestions. Its anonymous property helps to produce more candid answers than is possible in an interview. Interview schedules were used to guide interviews which were conducted among the Directors of departments on challenges facing the implementation of strategic plans in the Municipal Council of Eldoret.

\subsection{Data Analysis}

After all data was collected, the researcher conducted data sorting whereby the collected data was arranged to bring some order hence allowing systematic handing and storing of raw data. Obure (2002) stated that data sorting is actually the beginning of detection, correction and avoidance of errors occurring as a result of mix-ups. Data editing was then done, this involved reading through the filled in questionnaires and the interview schedules to spot any errors which occurred during data collection. Data coding was done after editing of data, it involved the creation of dummy variable names according to the set rules whereby responses were assigned numeric values that was processed by Statistical Programme for Social Sciences (SPSS). The codes were designed so as to minimize errors during data entry and also allow easy interpretation of results.

After data coding, data entry was done through the keying of data according to the designed codes along with the assembly of the variables which were required for analysis. Data cleaning was then done; this involved conducting final check on the data file for accuracy, erroneous data, completeness and consistency. This final validation check of the data was absolutely necessary to avoid having to go back to original questionnaires many times to correct errors during data analysis. The data was then processed whereby the prepared data was submitted to the SPSS processor which computed the data and hence released the results.

This research yielded both qualitative and quantitative data. Qualitative data was analyzed qualitatively using content analysis based on analysis of meanings and implications emanating from respondents information and documented data. According to Gray (2004) qualitative data provides rich descriptions and explanations that demonstrate the chronological flow of events as well as often leading to serendipitous (chance) findings. On the other hand, quantitative data was analyzed using various statistics including measures of central tendency, dispersion and asymmetry. Processed data was then presented in tables and explanation in prose.

\section{Results}

\subsection{Technological Resources}

The study findings indicated that majority of the respondents $108(49.1 \%)$ were of the view that the council had inadequate technological resources while minority $21(9.5 \%)$ were of a contrary view. This view was supported by a mean of 3.55 which was based on a likert scale of range between one to five where one represented strongly disagree with the issue, two disagree, three undecided, four agree and five strongly agree with the issue. The interpretations of these means were 1.1 to 1.6 indicated strongly disagree, 1.7 to 2.2 disagree, 2.3 to 2.8 undecided, 2.9 to 3.4 agree, while 3.5 to 5.0 strongly agree. This shows that majority of the respondents supported the above stated view. This could imply that council may have inadequate technological resources put in place towards the implementation of strategic plans hence affecting the implementation of the strategic plan. 


\subsection{Management Systems Put in Place towards Implementation of Strategic Plans}

The study findings indicated that majority of the respondents $94(42.7 \%)$ were of the view that the councils management systems were inefficient while minority $8(3.6 \%)$ were of a contrary view. This view was supported by a mean 3.10 on a likert scale of range between one to five where one represented strongly disagree with the issue, two disagree, three undecided, four agree and five strongly agree with the issue. The interpretations of these means were 1.1 to 1.6 indicated strongly disagree, 1.7 to 2.2 disagree, 2.3 to 2.8 undecided, 2.9 to 3.4 agree, while 3.5 to 5.0 strongly agree. This shows that majority of the respondents supported the above stated view. This could imply that the council might have put in place insufficient management systems hence effecting the implementation of her strategic plan.

\subsection{Control over the Implementation of Strategic Plan}

The study findings indicated that majority of the respondents $96(43.6 \%)$ were of the view that the council had insufficient control over the implementation of her strategic plans while minority $11(5.0 \%)$ were of the contrary view. This view was supported by a mean 3.04 which was based on a likert scale of range between one to five where one represented strongly disagree with the issue, two disagree, three undecided, four agree and five strongly agree with the issue. The interpretations of these means were 1.1 to 1.6 indicated strongly disagree, 1.7 to 2.2 disagree, 2.3 to 2.8 undecided, 2.9 to 3.4 agree, while 3.5 to 5.0 strongly agree. This shows that majority of the respondents supported the above stated view. This could imply that the council may be lacking control over the implementation of her strategic plans hence affecting its implementation.

\subsection{Management Approaches}

The study findings indicated that majority of the respondents $121(55.0 \%)$ were of the view that the management approaches used by the Council were inefficient while minority 5(2.3\%) were of a contrary view. This view was supported by a mean 3.21 which was based on a likert scale of range between one to five where one represented strongly disagree with the issue, two disagree, three undecided, four agree and five strongly agree with the issue. The interpretations of these means were 1.1 to 1.6 indicated strongly disagree, 1.7 to 2.2 disagree, 2.3 to 2.8 undecided, 2.9 to 3.4 agree, while 3.5 to 5.0 strongly agree. This shows that majority of the respondents supported the above stated view. This could imply that the council could be facing challenges in implementing her strategic plans due to insufficient management approaches.

\subsection{Support from the Central Government}

The study findings indicated that majority of the respondents $99(45.0 \%)$ were of the view that there was limited support from the central government towards the implementation of the councils strategic plan while Minority $21(9.5 \%)$ were of the contrary view. This view was supported by a mean 3.12 which was based on a likert scale of range between one to five where one represented strongly disagree with the issue, two disagree, three undecided, four agree and five strongly agree with the issue. The interpretations of these means were 1.1 to 1.6 indicated strongly disagree, 1.7 to 2.2 disagree, 2.3 to 2.8 undecided, 2.9 to 3.4 agree, while 3.5 to 5.0 strongly agree. This shows that majority of the respondents supported the above stated view. This could imply that the council may be facing insufficient support from the central government.

\section{Conclusion}

Focusing on the effects of institutional related factors affecting the implementation of strategic plans, it was concluded that there was inadequate technological resources, insufficient management systems, and the council lacked control over the implementation of her strategic plan, insufficient management approaches and inadequate support from the central government towards the implementation of the council's strategic plan were also determined.

The study concluded that employees should be trained on various matters concerning the implementation of strategic plans. There should be availability of information on issues of strategic plans therefore the management of the council should ensure that all information concerning strategic plans is at the disposal of all the employees. All employees should be involved in making decisions on matters focusing on implementing strategic plans. Therefore, the council's management should be inclusive in all matters focusing on strategic plans. It should allow all the staff members to participate fully from the formulation until the evaluation of her strategic plan. The central government should allocate enough funds in time others resources to the Local Authorities so as to necessitate speedy implementation of the strategic plan. Recruitment of more expertise with experience on financial management should be done moreover more employees should be recruited hence assisting in the implementation of the strategic plan. 


\section{Acknowledgements}

I greatly acknowledge the assistance from my Academic Supervisors, Dr. Cleophas Maende and Dr. John Bonuke, lecturers, classmates and mentors who have enabled me to effectively design this research paper. Great thanks to the Family of the Late Eng. S.E Buluma for the great support especially my Mother Mrs. Lucy Buluma, Brothers Eric, Lawrence and sisters Susan, Violet, Elizabeth and Monica for the moral and financial support.

\section{References}

Alexander, L. D. (1985). Successfully Implementing Strategic Decisions. Long Range Plan, 18(3), 91-97. http://dx.doi.org/10.1016/0024-6301(85)90161-X

Borg, W. R., \& Gall, M. D. (1989). Education Research: An Introduction (4th ed.). New York: Longman.

Chimhanzi, J., \& Morgan, R. E. (2005). Explanations from the marketing/human resources dyad for marketing strategy implementation effectiveness in service firms. Journal of Business Research, 58(6), 787-796. http://dx.doi.org/10.1016/j.jbusres.2003.11.003

Economic Commission of Africa. (2003). Public sector Management Reforms, Ethiopia.

Forman, J., \& Argenti, P. A. (2005). How Corporate Communication Influences Strategy Implementation, Reputation and the Corporate Brand: An Exploratory Qualitative Study. Corporate Reputation Review, 8, 245-264. http://dx.doi.org/10.1057/palgrave.crr.1540253

Gay, L. R. (1992). Educational Research, Competences for Analysis and Application. Ohio: Charles E. Merill Publishing, Co.

Gray, D. E. (2004). Doing Research in the Real World. London: Sage Publications.

Heide, M., Gronhaug, K., \& Johannessen, S. (2002). Exploring Barriers to The Successful Implementation of a Formulated strategy. Scandinavian Journal of Management, 18(2), 217-231. http://dx.doi.org/10.1016/S0956-5221(01)00007-0

Hope, K. R. (2001). The New public Management: Context and Practice in Africa. International Public Management Journal, 4(2), 119-134. http://dx.doi.org/10.1016/S1096-7494(01)00053-8

Hrebiniak, L., \& Joyce, W. (1982). Implementing Strategy. NewYork: Macmillian.

Mugenda, O., \& Mugenda, A. (1999). Research Methods: Qualitative and Quantitative Approaches. Nairobi: Acts Press.

Noble, C. H. (1999). The Eclectic Roots of Strategy Implementation Research. Journal of Business Research, 45(2), 119-134. http://dx.doi.org/10.1016/S0148-2963(97)00231-2

Nutt, P. C. (1986). Tactics of Implementation. Academy of Management Journal, 29(2), 230-261. http://dx.doi.org/10.2307/256187

Nutt, P. C. (1987). Identifying and Appraising How Managers Install Strategy. Strategic Management Journal, 8(1), 1-14. http://dx.doi.org/10.1002/smj.4250080102

Obure, M. J. (2002). Handbook on data analysis using SPSS. M\&O Data Experts Training and Consultants, Nairobi.

Orodho, J. A. (2002). Techniques of Writing Research Proposals and Reports in Education and Social Sciences. Nairobi: Masola Publishers.

Rapert, M. I., Velliquette, A., \& Garretson, J. A. (2002). The Strategic Implementation Process Evoking Strategic Consensus through Communication. Journal of Business Research, 55(4), 301-310. http://dx.doi.org/10.1016/S0148-2963(00)00157-0

Schmidt, S. L., \& Brauer, M. (2006). Strategic Governance: How to Assess Board Effectiveness in Guiding $\begin{array}{llll}\text { Strategy Execution. } & \text { Strategic } & \text { Governance, } & 14(1),\end{array}$ http://dx.doi.org/10.1111/j.1467-8683.2006.00480.x

Smith, K. A., \& Kofron, E. A. (1996). Toward a research agenda on top Management teams and strategy implementation. Irish Business and Administrative Research.

Wright, M., \& McMahan, C. (1992). Theoretical perspectives for strategic human resource management. Journal of Management, 18, 295-320. http://dx.doi.org/10.1177/014920639201800205

Yang. (2008). Making strategy work, a literature review on Factors influencing strategy implementation. ICA working paper, $2 / 2008$, Institute of corporate communication. 